\title{
Migracyjne kino „w drodze”
}

\author{
MAŁGORZATA RADKIEWICZ
}

Filmy pokazujące zjawisko przymusowej migracji z powodów ekonomicznych czy politycznych - naznaczonej granicami, strachem, niepewnością - należałoby raczej nazwać kinem „w drodze” niż kinem drogi. Zamiast wpisanej w formułę gatunkową ekscytacji nieznanym, poczuciem buntu, wyzwolenia i transgresji, dominuje tu przymus wędrówki bez odwrotu, podejmowanej w sytuacjach niepozostawiających wyboru, w poszukiwaniu ocalenia, bezpieczeństwa, lepszych warunków życia. Dramatyczne przeżycia związane z migracją wpływają na uformowanie się opisanej przez Hamida Naficiego w „filmach granicznych” ,granicznej świadomości” (border consciousness) ${ }^{1}$, charakteryzującej się poczuciem liminalności, ambiwalencji i chaosu ${ }^{2}$. Graniczność występuje w analizach kina postkolonialnego, gdzie łączy się często z doświadczeniem diaspory i podtrzymywanych w niej tradycji oraz wspomnień dotyczących migracji ${ }^{3}$. Do natury granic i ich funkcji odwołuje się w swoich badaniach Michel Agier, który konsekwentnie śledzi szlaki współczesnych uchodźców oraz miejsca ich czasowych - co nie oznacza krótkich - postojów i siedlisk. Jego rozważania są interesujące nie tylko ze względu na swoją aktualność, ale także $\mathrm{z}$ uwagi na podjęty $\mathrm{w}$ nich dialog z ideami ponowoczesności i globalizacji diagnozowanymi przez Zygmunta Baumana. Co ciekawe, filozof w odpowiedzi włączył się do debaty intelektualnej, znajdując w opisach Agiera ilustrację swoich tez. Nazwał go nawet jednym z najbardziej przenikliwych, wytrwałych oraz najlepiej poinformowanych badaczy losów ponad dwustu milionów ludzi, którzy do dnia dzisiejszego (w skali globalnej) opuścili swoje domy. Natomiast Agier odnalazł u Baumana wątki - także krytyczne - które wykorzystał w swoich rozważaniach na temat tego, co w sensie antropologicznym oznacza dziś bycie człowiekiem. Dlatego spośród licznych głosów i koncepcji dotyczących życia „w drodze” chcę się skupić tylko na tych dwóch, znajdując w nich i namysł teoretyczny, i odwołania do konkretnej rzeczywistości historycznej oraz społecznej, której obrazy można odnaleźć w kinie współczesnym.

We wstępie do swojej książki o „marginesach świata” ${ }^{4}$ Agier wyjaśnia, że choć planował ją jako zbiór refleksji antropologicznych, to w trakcie pisania nabrała ona cech alarmujacego przesłania ${ }^{5}$ do znacznie szerszej publiczności niż środowisko akademickie. Autor zaznacza, że nie chodziło mu o wywołanie efektu rewelacji czy skandalu - co jego zdaniem zazwyczaj prowadzi do umocnienia obaw i uprzedzeń wobec obcych - ale raczej o dostarczenie wiedzy pomagającej w zrozumieniu problemu uchodźstwa, marginalizacji i wykluczenia całych grup z dostępu do dóbr, przestrzeni i władzy.

Podobne ujęcia opisowo-interwencyjne zawierają filmy fabularne i dokumentalne ukazujące $\mathrm{z}$ antropologiczną wnikliwością uchodźców „w drodze”, wymuszające uważność oglądu i zaangażowanie emocjonalne. To właśnie podobieństwo 
punktów widzenia, wrażliwości i stopnia zaangażowania twórców, a nie poetyka czy stylistyka realizacji, byłoby wspólną płaszczyzną dla przywołanych w poniższym tekście tytułów, składających się na wielowątkową panoramę współczesnego uchodźstwa. Wydaje się, że zarówno autorzy fabuł, jak i dokumentów podążali za wskazówką Agiera, by skupiać się na sytuacjach społecznych oraz przeżyciach i doznaniach migrujących ludzi pozbawionych zaplecza rodzinnego i kulturowego. Migracyjne kino „w drodze” miałoby więc charakter antropologiczny i aktywistyczny, jak prace francuskiego badacza, stawiając sobie cele poznawcze, a równocześnie wywołując zaangażowanie emocjonalne (także prowokując postawy krytyczne). Filmy te ze względu na podejmowane tematy, miejsce akcji i typy bohaterów można analizować za pomocą tej samej metody, jaką zastosował Agier w badaniach nad szlakami uchodźców i miejscami ich pobytu. Z przyjętej przez niego perspektywy antropologicznej w ludzkie doświadczenie exodusu-wygnania-ucieczki są wpisane trzy etapy wyznaczone przez momenty kluczowe dla „tułaczego życia" (wandering life) ${ }^{6}$.

Pierwszy to etap destrukcji i rozpadu, którego początek jest związany najczęściej z wojną lub konfliktem zbrojnym burzącym porządek zwykłego życia i przerywającym jego ciągłość. Ucieczka, choć postrzegana jako jedyny ratunek, okazuje się równie destrukcyjna jak wcześniejsze wydarzenia, ostatecznie pozbawiając uchodźców poczucia bezpieczeństwa, bliskości, a często także tożsamości zwłaszcza gdy dokumenty identyfikacyjne zostają zniszczone. Przebyta droga prowadzi do kolejnego etapu, jakim jest symboliczne i fizyczne uwięzienie. Uchodźcy zamknięci w obozach, na obrzeżach miast, w portach i obszarach przygranicznych, skupieni w tymczasowych koczowiskach są skazani na miesiące lub nawet lata oczekiwań na tranzyt czy legalizację pobytu. Na końcu przychodzi etap działania, kiedy uchodźcy początkowo niepewnie zaczynają domagać się prawa do godnego życia, podmiotowego traktowania i swobodnej wypowiedzi. Ich żądania postrzegane najczęściej jako nielegalne zostają tłumione, lecz zdaniem Agiera mogą czasem dać początek nowym formom zaangażowania politycznego. Kolejne etapy łączą się ściśle ze sobą, tworząc trzy sekwencje tego samego kontekstu egzystencjalnego ${ }^{7}$ układające się w życie tułaczy. Problemy i konsekwencje wynikające z tułaczego trybu życia tak dużych grup ludności wynikają, zdaniem Baumana, między innymi z tego, że odkryliśmy dotąd ignorowany przesmyk między ,,dwiema kategoriami świata”: przejście przegapione przy wcześniejszych (...) próbach utrzymania obu kategorii w bezpiecznej-czytaj: „, nieprzekraczalnej”-odległości od siebie ${ }^{8}$.

W swoich tekstach Agier używa konsekwentnie określenia „uchodźcy”, pragnąc podkreślić kontekstowe uwarunkowania opisywanych problemów oraz ich ważność i złożoność. Jak zwraca uwagę Giulia Scalettaris, wbrew ułomnym i redukcjonistycznym definicjom, termin , migrant” oznacza każda osobę, która opuszcza swój kraj, natomiast termin „uchodźca” odnosi się do osób, które były zmuszone opuścić kraj, by uciec przed niebezpieczeństwem, takim jak wojna, prześladowanie, itp. ${ }^{9} \mathrm{~W}$ konsekwencji podpisania w 1951 roku konwencji genewskiej pojęcie uchodźcy stało się kategorią prawną, związaną z koniecznością ochrony ludzi zagrożonych prześladowaniami ze względów politycznych, religijnych, rasowych, narodowościowych lub społecznych. Jednak polemiki toczące się wokół kwestii przyjmowania cudzoziemców nieeuropejskich zaostrzyły różnice w interpretacji 
kategorii - i związanych z nimi praw - „migrant” i „uchodźca”, zależnie od powodów wyjazdu (ekonomicznych lub politycznych) lub nawet narodowości. Zwolennicy podejścia, że wszyscy migrujący mają równe prawa, proponują, by wyjść poza te binarne określenia i używać terminów: cudzoziemcy, wygnańcy, przesiedleńcy. Autorka podsumowuje swoje rozważania stwierdzeniem, że opozycja uchodźca - migrant jest pewnym uproszczeniem, które utrwala różnice trudne do wykazania w praktyce ${ }^{10}$. Należy więc pamiętać, że powody wyjazdów mogą być bardzo różnorodne i w rozmaity sposób ze sobą powiązane, obejmując także formy przymusu, jakich nie zapisano w konwencji genewskiej.

\section{W drodze}

Agier pisał swoją książkę o uchodźcach (2005) z perspektywy wydarzeń 2001 r., podkreślając, że na wzmożenie migracji miały wpływ i atak na World Trade Centre, i nasilająca się interwencja amerykańska w Afganistanie, która spowodowała wielomilionowy przepływ ludności do Pakistanu, Iranu i innych państw. Jako kraje masowego exodusu wymienia również: Somalię, południowy Sudan, Czeczenię i Kolumbię, uznając losy wszystkich uchodźców za emblematyczne dla ludzkiej kondycji, która została ukształtowana na marginesach świata ${ }^{11}$. Zestawienie filmów: Na tym świecie (In this World, 2002) Michaela Winterbottoma oraz 14 kilometrów (14 kilómetros, 2007) Gerardo Olivaresa pozwala odtworzyć dwa najbardziej „uczęszczane” szlaki uchodźcze: azjatycki i afrykański. Narracja wpisana w te trasy zawiera wszystkie elementy składające się na etap destrukcji i przymusowego przesiedlenia, prowadzący ku (bez)czasowemu uwięzieniu. Ponadto oba tytuły doskonale odzwierciedlają ideę zmarnowanego życia (wasted lives) Zygmunta Baumana, do której odwołał się Agier, opisując sytuację ludzi „w drodze”. Książka Baumana Życie na przemiał powstała na progu nowego tysiąclecia, kiedy stało się widoczne, że nieuniknionym skutkiem modernizacji i globalizacji jest kultura odrzucenia. Następuje w niej produkcja ,,ludzi-odpadów”, ,,ludzi-odrzutów”, czy też , ludzi na przemiat”" ${ }^{12}$, których tylko migracja jest w stanie uchronić przed losem, jakim jest przeznaczenie na śmietnik ${ }^{13}$. Bauman podkreśla, że wyjazd to często sposób ucieczki przed masakrami, wojnami plemiennymi, za pomocą których spóźnieni adepci nowoczesności ${ }^{14}$ próbują rozwikłać w skali lokalnej dotykające ich problemy zglobalizowanego świata. Z tej perspektywy migracja z regionów nieustających konfliktów (Afganistan, Bliski Wschód, Afryka) ma zarówno charakter polityczny, jak i ekonomiczny. Wymusza ją przewlekła nędza, cierpienie oraz skutki „deregulacji wojen” czyli prowadzenia działań wojennych przez formacje pozapaństwowe, które nie przestrzegają praw żadnego kraju i żadnych międzynarodowych konwencji ${ }^{15}$.

Scenariusz do filmu Michaela Winterbottoma Na tym świecie powstał na podstawie rozmowy przeprowadzonej przez Toniego Grisoniego w obozie w Peszawarze w Afganistanie, gdzie od lat 70. XX w. gromadzili się ludzie uciekający najpierw przez wojskami radzieckimi, potem przed Talibami i nasilającymi się nalotami Amerykanów. Z zebranych materiałów wyłoniła się złożona narracja o uchodźcach, do której zostały dopisane wątki z wywiadów z emigrantami starającymi się o azyl w Wielkiej Brytanii. Związek pomiędzy rzeczywistością a fabularną historią dwóch chłopców otrzymujących od krewnych wsparcie i pieniądze, 
by przedostać się do Europy, wzmacniał fakt, że w główne role wcielili się nastoletni uchodźcy: Jama Udin Torabi (jako Jama) i Enayatullah (jako Enayat). Natomiast drugoplanowe postacie zagrali ich prawdziwi krewni i przyjaciele, wnoszący do realizacji własne doświadczenia uchodźcze i przeżycia. Dla młodocianych aktorów od początku było jasne, że za swoją pracę otrzymają pieniądze, ale po zakończeniu podróży udokumentowanej przez kamerę zostaną odesłani do Afganistanu. Postanowienia dotrzymano, jednak po powrocie młodszy chłopiec Jamal zdecydował się podzielić los swojego bohatera i już bez ekipy ponownie pokonał całą trasę. Udało mu się nielegalnie przedostać do Londynu, gdzie dostał pozwolenie na pobyt do czasu uzyskania pełnoletniości.

Bohaterowie filmu Winetrbottoma przemierzają trasę niemal pokrywającą się z historycznym Jedwabnym Szlakiem, podróżując różnymi środkami lokomocji, w tym w zamkniętym kontenerze albo na piechotę. Zmieniające się krajobrazy oraz warunki atmosferyczne nadają rytm ich wyprawie, wyznaczając geograficzne fazy przeprawy i wpisane w nie przeszkody. Uchwycone przez kamerę uderzające piękno górskich i pustynnych przestrzeni pozostaje jakby poza zasięgiem wzroku chłopców, którzy skupieni na podróżniczych zmaganiach nie mają poczucia, że jest to dla nich wyprawa poznawcza. Wysiłek włożony w pokonywanie każdego odcinka jest zbyt duży, by pozostawała energia na rozglądanie się po świecie i entuzjazm dla czegoś więcej niż odpoczynek. Jedyna scena, w której chłopcy skupiają się na krajobrazie, pokazuje ich siedzących w Turcji naprzeciwko gór stanowiących kolejne wyzwanie na trasie do Europy. Jama mówi do Enayata: Patrz, jaki widok! A ten odpowiada: Popatrz na śnieg, jaki jest ładny. Wkrótce okaże się, że ośnieżone szczyty stanowią dla wędrowców prawdziwą pułapkę, a nie żadną atrakcję. Dokumentalny styl filmowania $\mathrm{z}$ wykorzystaniem małej kamery cyfrowej nadaje subiektywny charakter oglądanym obrazom i sprawia, że spojrzenie widza, nawet jeśli skupia się na pięknych krajobrazach, to jednak częściej nakłada się na punkt widzenia migrujących chłopców.

Azjatycką trasę migracji, udokumentowaną przez Winterbottoma w Na tym świecie, wyznaczają punkty krytyczne: naturalne, jak pustynia czy pasma górskie i administracyjne, jak granica irańsko-turecka, na której patrolujący żołnierze gotowi są strzelać do nielegalnych podróżników. Kluczowym etapem jest przeprawa z Turcji do Triestu, którą młodzi bohaterowie odbywają ukryci w ciężarówce, wraz z młodym małżeństwem i ich dzieckiem. Kiedy w końcu po czterdziestu godzinach docierają na włoskie wybrzeże, okazuje się, że tylko najmłodsi uczestnicy przeżyli tę podróż, reszta udusiła się w ciasnym transporterze. Przemytnicy niespecjalnie przejmują się ich śmiercią, kalkulując, jak zarobić na sprzedaży ocalałych pasażerów. Jamalowi udaje się uciec. Za skradzione pieniądze kupuje bilet na pociąg do Francji i na okres trwania przejazdu staje się jednym ze zwykłych podróżników. Jednak jest to tylko krótki okres przejściowy przed etapem uwięzienia, bowiem gdy tylko chłopiec dociera do obozu we francuskiej miejscowości Sangatte, znowu staje się nielegalnym uchodźcą marzącym o przedostaniu się do Wielkiej Brytanii.

W recenzjach z Na tym świecie pojawiły się zarzuty o mieszanie prawdy i fikcji, na które Winterbottom zareagował stwierdzeniem, że jego film z założenia grą z tym, co jest prawdziwe, a co fikcyjne: Weźmy Jamala. Jest afgańskim uchodźca; jego rodzice sq uchodźcami (...). Większość jego rodziny mieszka w obozach blisko tego, w którym byty zdjęcia. (...) Jeśli chcieliśmy coś zmienić, to zmienialiśmy, no 
$i$ wszystkie zdarzenia nielegalne albo niebezpieczne byty inscenizowane. (...) Ale zazwyczaj staraliśmy się wykreować sytuacje, w których ludzie nie musieli grać ${ }^{16}$. Bez względu na stopień fabularyzacji wydarzeń niezaprzeczalny pozostawał problem uchodźców, podany pod dyskusję między innymi za sprawą prasowych omówień filmu.

Inspiracją do powstania filmu 14 kilometrów - tyle wynosi szerokość Cieśniny Gibraltarskiej w najwęższym miejscu - były obserwacje Gerardo Olivaresa, który w trakcie kręcenia dokumentu Karawana (Caravan, 2005) o transporcie soli przez pustynię Tenéré nieustannie napotykał na grupy uchodźców nielegalnie przemierzające afrykański kontynent. W swoim debiucie fabularnym postanowił odtworzyć trasę, jaką pokonują przedstawiciele plemion z obszaru Sahary próbujący przedostać się do lepszego świata. Bohaterami fabularnej opowieści są dwaj bracia z Mali oraz kobieta z Nigru, odgrywani przez nieprofesjonalnych aktorów. Za każdą postacią i jej decyzją o migracji stoi indywidualna historia, która zostaje pokazana jako prolog podróży, z jednej strony uzasadniając jej konieczność, a z drugiej uzmysławiając ogrom wiązanych z nią nadziei. Violet chce wyjechać, ponieważ uboga rodzina zadecydowała o jej ślubie ze starszym mężczyzną, który ją molestował, gdy była młodsza. Buba jest utalentowanym piłkarzem i trener zachęca go do wyjazdu, by rozwinął swoje umiejętności sportowe. Mukela, który kibicuje karierze brata, postanawia mu towarzyszyć. Cała trójka wierzy w szansę, jaką oferują im przemytnicy, przekonujący że w odróżnieniu od biednych obszarów, z których się wywodzą, Europa jest prawdziwym rajem.

Wspólna historia bohaterów filmu Olivaresa rozpoczyna się od spotkania w Agaderze będącym głównym punktem przerzutowym przez Saharę, Maroko i Morze Śródziemne, pieszo albo przeładowanymi autobusami. Już na trasie pasażerowie zostaną podzieleni na grupy, z których jedna uda się do Algierii i Maroka, a druga do Libii. Filmowa scena podziału odtwarza sytuację, którą reżyser zaobserwował na pustyni, gdzie ludzie wyrzuceni ze środków transportu byli selekcjonowani przez swoich przewodników do dalszej podróży, do której byli zresztą zupełnie nieprzygotowani. Bohaterom filmu udaje się uniknąć losu uchodźców przechwyconych w Maroku albo w Algierii, gdzie tworzy się tymczasowe, przygraniczne obozy. Jednak kiedy Buba i Violet docierają w końcu łodzią do Hiszpanii, natychmiast stają się ofiarami pościgu - gdyby zostali złapani, natychmiast by ich deportowano. Reżyser świadom dramatyzmu podobnych aktów w rzeczywistości, przynajmniej w swoim filmie pragnie dać uchodźcom szansę - strażnicy pozwalają im uciec.

Agier zwraca uwagę na fakt, że to na naszych oczach i we współczesnych nam czasach wyłania się świat przemieszczonych i uchodźców: rezultat brudnych wojen, terroru (...) przepraw i formowania nowych obozów (...) spektakl anonimowych ofiar ${ }^{17}$. Bezpośredniości i teraźniejszości tych zdarzeń doświadcza bohaterka filmu Styks (Styx, 2018) w reżyserii Wolfganga Fischera. Akcja rozpoczyna się od scen na ulicach Hamburga, gdzie ekipa karetki pogotowia udziela pomocy ofierze wypadku. Sprawność i skuteczność działania lekarki Rake (Susanne Wolff) nie pozostawia wątpliwości, iż poradzi sobie ona w planowanym samotnym rejsie, o którym informuje kolegów. Kobieta wyrusza swoim jachtem wzdłuż wybrzeży Afryki, by poznać znaną jej z barwnego albumu Wyspę Wniebowstąpienia z jej endemiczną przyrodą. Rytm filmowych zdarzeń jest podporządkowany rutynie wy- 
prawy: nawigacji, łączności ze strażą przybrzeżną i rzadko mijanymi statkami, śledzeniu komunikatów atmosferycznych. Gdy wydaje się, że największym wyzwaniem będą zmagania z nocnym sztormem, na horyzoncie pojawia się niezidentyfikowana łódź wypełniona afrykańskimi uchodźcami. Z przepełnionego pokładu dobiegają wołania o pomoc, a pojedyncze osoby wskakują nawet do wody, usiłując płynąć po ratunek. Pierwszą reakcją Rake jest nadanie przez radio komunikatu o tonącej jednostce, w nadziei na skuteczność służb bezpieczeństwa. W odpowiedzi, zamiast gwarancji szybkiej interwencji, pojawia się jednak ostrzeżenie, by nie zbliżała się zbytnio do zagrożonego obiektu i nie podejmowała żadnych samodzielnych kroków. Z jednej strony wytrawnej żeglarce i wykwalifikowanej lekarce trudno się pogodzić z autorytarnie narzuconą biernością, sprzeczną z jej zasadami osobistymi i zawodowymi, choć z drugiej strony pragmatyka - świadomość ilości zapasów wody, pojemności i wytrzymałości pokładu - powstrzymuje ją przed natychmiastową reakcją.

Film Fischera potwierdza obserwację Baumana, że problemy związane z tak zwanym kryzysem migracyjnym oraz lękiem przed migrantami zaliczają się do najbardziej złożonych i kontrowersyjnych, bowiem w obliczu masy obcych stojących u bram dochodzi do konfliktu między paraliżującym strachem a impulsem etycznym pojawiającym się na widok ludzkiego nieszczęścia. Bohaterka Styksu przeżywa wewnętrzne zmagania z własną wolą i moralnością, doświadczając, że: Każdy z nas w pewnym momencie może stać się jednocześnie polem bitwy, żołnierzem $i$ sędzia w takiej walce ${ }^{18}$. Przełom w postępowaniu Rake następuje wówczas, gdy do jachtu podpływa wycieńczony chłopiec, w dodatku poparzony środkami chemicznymi rozlanymi na nieszczelnej łodzi. Kobieta nie tylko opatruje go i karmi, ale po wysłuchaniu jego opowieści, nadaje przez radio szczegółową relację ze swoich działań, uprzedzając, że jeśli wkrótce nie pojawią się jednostki ratunkowe to sama popłynie z pomocą. Mijają godziny, a na pokładzie tonącej łodzi cichną zrozpaczone głosy. Rake nie zastanawia się już dłużej i wciąga kotwicę, by po chwili wejść na pokład zasłany bezwładnymi ciałami. Ostatnie sceny filmu pokazują umundurowanych strażników wynoszących nieżywych oraz rannych i wyprowadzających aresztowaną lekarkę, niepróbującą się ani bronić, ani tłumaczyć.

Dylematy ukazane w filmie Styks powróciły jako realny temat na pierwszych stronach gazet na początku lipca 2019 roku, gdy świat obiegła informacja o aresztowaniu kapitan Caroli Rackete, która swoim statkiem „Sea-Watch 3” uratowała na Morzu Śródziemnym 40 emigrantów i wbrew zakazom włoskich władz przywiozła ich na Lampedusę. Niemiecka aktywistka i działaczka ekologiczna powiedziała dziennikarzom, że zdaje sobie sprawę z dokonanego aktu obywatelskiego nieposłuszeństwa, ale zrobiła to po to, by przypomnieć, że oprócz arbitralnych regulacji istnieje coś takiego, jak prawa człowieka ${ }^{19}$. Postawy rzeczywistej kapitan Rackete oraz fabularnej Rake odzwierciedlają napięcie, jakie zdaniem Baumana jest nierozerwalnie związane z kontaktem z obcym, oscylującym między wrogością a empatią: Rzadko kiedy moralność staje przed trudniejszym wyzwaniem, jak wtedy, gdy stara się nagiąc wole do swoich rozkazów. Rzadko kiedy wola musi się zmierzyć z cięższym zadaniem, jak wtedy, gdy chce pozostać glucha na wyzwania moralności ${ }^{20}$. 


\section{Na marginesach świata}

Filmy o uchodźcach pokazują, że trudne wybory nie znikną, jeśli nie zmieni się polityka migracyjna podtrzymująca podział na czysty, zdrowy, widzialny świat z jednej strony i na świat ,, ludzkich resztek”, ciemny, chory i niewidoczny ${ }^{21} \mathrm{z}$ drugiej. Jak zwraca uwagę Agier w analizie drugiego etapu uchodźctwa - uwięzienia, w konsekwencji tego podziału będą powstawać kolejne obozy, które nie będa już stużyly do utrzymywania potrzebujących pomocy uchodźców przy życiu, ale do lokowania i pilnowania wszelkich niepożadanych grup ${ }^{22}$. Francuski badacz śledzi miejsca zamieszkane przez Baumanowskie ludzkie resztki, przemierzając niezliczone obozowiska, kilometry korytarzy tranzytowych, wyspy, platformy na morzu oraz zagrody na środku pustyni. We wszystkich tych miejscach zauważa, że są one starannie wydzielone, otoczone murami, zasiekami z drutu kolczastego, płotami, a czasem tylko przytłaczającą pustką.

Podobne obserwacje zawiera esej Giorgio Agambena uznającego, że pozornie marginalna postać uchodźcy zasługuje raczej na to, by traktować ja jako centralna dla naszej historii politycznej ${ }^{23}$. Jeśli dostrzeże się w niej ciągłość nurtu migracyjnego, widoczne stanie się, że powstawanie obozów to konsekwentne działanie polegające na wydzielaniu przestrzeni, w której stan wyjątkowy zaczyna się stawać regułą. A to, co wydawało się czasowym zawieszeniem porządku w celu zagwarantowania bezpieczeństwa, nabiera cech stałego ładu przestrzennego, który jako taki pozostaje jednak stale poza normalnym porządkiem ${ }^{24}$. Konsekwencją wydłużania się tymczasowości obozów jest ich specyficzny status. Powoduje on, że każde z obozowisk zostaje wyłączone z normalnego porządku prawnego, co jak zaznacza Agamben, wcale nie sprawia, że staje się przez to po prostu przestrzenia leżaca na zewnatrz. To, co jest $w$ nim wytaczone, jest - zgodnie z etymologicznym sensem terminu ,, wyjątek”- wyjęte, wyłączone poprzez własne wyłaczenie ${ }^{25}$. Rozważania te wykorzystuje Paweł Mościcki w swoich analizach filmów i prac artystycznych, w których obóz jawi się jako „przestrzeń pomieszania” - jednocześnie wyłączona z systemu i podtrzymująca jego funkcjonowanie ${ }^{26}$.

Takim miejscem jest również obóz dla uchodźców w Sangatte, do którego dociera bohater filmu Na tym świecie Winterbottoma. Obóz został założony w 1999 r. w pobliżu wjazdu do Eurotunelu pod kanałem La Manche. Dla bohatera filmu strategiczny punkt podróży. Prowizoryczne obozowisko już po trzech latach istnienia zamiast planowanych 600 mieszkańców, miało ich ponad półtora tysiąca, co przyczyniło się do jego całkowitego zamknięcia w 2002 roku. W tym samym czasie w okolicach Calais zaczęły coraz liczniej powstawać podobne obozy, z których największy, zwany potocznie „Dżunglą”, w okresie najintensywniejszego funkcjonowania od 2015 do momentu likwidacji w październiku 2016 roku dawał schronienie ponad ośmiu tysiącom uchodźców.

Sytuację uchodźców skupionych w strategicznych punktach wokół Calais pokazał film Witamy (Welcome, Philippe Lioret, 2009), którego ironiczny tytuł odzwierciedla napięcia typowe dla podobnych miejsc, opisane przez Agiera. Młody Kurd Bilal nielegalnie przebywa trasę z Iraku, chcąc przedostać się do ukochanej dziewczyny mieszkającej w Wielkiej Brytanii. We francuskim obozowisku poznaje mężczyzn, którzy mają ten sam cel i są gotowi na desperacką podróż w kontenerach ciężarówek, byleby tylko przekroczyć kanał. Dzięki ich pomocy Bilal dostaje się 
do transportu, ale aby ukryć się przed strażnikami i ich psami, musi na czas kontroli założyć na głowę foliowy worek, tłumiący oddech. Ku zaskoczeniu współpodróżników w decydującym momencie chłopak zrywa folię z twarzy, a jego oddech zwraca uwagę patrolu. Wściekłym współpasażerom wyjaśnia, że doświadczenia z tureckiej granicy nie pozwalają mu pokonać paraliżującego strachu przed uduszeniem. Równie szalony i niebezpieczny jest pomysł Bilala, by pokonać wpław 32-kilometrowy dystans z Calais do Dover. Pierwsza próba, niepoprzedzona żadnym treningiem, kończy się niepowodzeniem. Wycieńczonego siedemnastolatka znajduje na plaży lokalny instruktor pływacki. Początkowo mężczyzna jest zdenerwowany samym spotkaniem z nielegalnym mieszkańcem, ale z czasem odzywa się w nim natura byłego sportowca rozumiejącego ekscytację wyzwaniem i pragnienie pokonania swoich słabości. Postanawia więc szkolić młodego Kurda i mimo że cel nie ma charakteru sportowego, tworzy się między nimi relacja mistrz-uczeń, niemieszcząca się w schematach kontaktów z egzotycznymi przybyszami.

Uchodźcy znający Bilala zazdroszczą mu nie odwagi ani umiejętności pływackich, lecz regularnych wizyt na basenie, dzięki czemu jest on zawsze czysty, podczas gdy oni nie mają w obozie regularnego dostępu do łazienek. Wolontariusze dostarczają im wprawdzie odzieży i jedzenia, jednak higiena jest czymś znacznie bardziej luksusowym. Podobnie jak swoboda poruszania się po okolicznym terenie, pilnie patrolowanym przez strażników, którzy dbają, by obcy pozostawali poza obszarem funkcjonowania lokalnych mieszkańców - mających zresztą zakaz kontaktu z obozowiczami. W filmie Witajcie zostaje zobrazowana „forma obozu”, w której Agier dostrzegł trzy zasadnicze czynniki: wyjątkowy status prawny i polityczny, eksterytorialność oraz wykluczenie na poziomie struktury społecznej ${ }^{27}$. Cechy te są wykorzystywane do wykreowania i podtrzymywania fikcji czegoś ,,na zewnątrz” (...) Takie wykluczenie migrantów, jeśli utrzyma się jako trwałe rozwiązanie-może doprowadzić do stworzenia ludzi drugiej kategorii" ${ }^{28}$. Francuski badacz odwołuje się w swojej analizie do przykładów z XX-wiecznej Francji i choć przypomina, że oficjalne obozy dla napływającej obcej ludności nie są w Europie czymś nowym, to zaznacza, że to właśnie we współczesności nabrały szczególnego znaczenia. Obozowiska pojawiające się od Lesbos po Calais przy granicach, w miastach, na opuszczonych terenach, w ruinach i porzuconych budynkach, coraz częściej zaczynają pełnić rolę ośrodków przetrzymywania i wydalania migrantów, którzy często nie mogą nawet złożyć wniosku o azyl. W efekcie stało się widoczne przesunięcie od racji humanitarnych, które a priori sa bezdyskusyjne, ku ewidentnym względom bezpieczeństwa ${ }^{29}$ - co jego zdaniem jest typowe dla dwuznacznego charakteru zamykania ludzi w obozach.

O zmaganiach z napięciem między powinnościami humanitarnymi a kwestiami bezpieczeństwa opowiadają filmy rozgrywające się w dwóch, obok Calais, najbardziej strategicznych punktach uchodźczych w Europie. Pierwszym jest włoska wyspa Lampedusa, której legalni i nielegalni mieszkańcy zostali sportretowani w filmie dokumentalnym Ogień na morzu (Fuocoammare, 2017) w reżyserii Gianfranco Rosiego, drugim nieczynne lotnisko Tempelhof w Berlinie, ukazane w dokumencie Central Airport TPH (2018) przez Karima Aïnouza.

Położenie geograficzne czyni z Lampedusy pierwszy skrawek zachodniego lądu, do którego docierają uchodźcy przemierzający Morze Śródziemne z Afryki, najczęściej na łodziach zupełnie nieprzygotowanych do transportu dalekomor- 
skiego. Dlatego Ogień na morzu - zdobywca Złotego Niedźwiedzia na 67. Festiwalu Filmowym w Berlinie - koncentruje się na trzech wątkach transferowych: nadzorowania wybrzeża i przekazywania informacji o kolejnych eskapadach przemytniczych, udzielania pomocy ofiarom tego procederu i organizowania pobytu uchodźcom. Tłem tych działań - jeszcze sprzed zaostrzenia przez Włochy polityki migracyjnej - jest codzienne życie mieszkańców wyspy, rybaków, ludzi morza podchodzących do niego $\mathrm{z}$ respektem i niezastanawiających się nad powinnością pomocy wobec jego ofiar. Wśród sportretowanych mieszkańców jest lokalny radiowiec, którego rodzina $\mathrm{z}$ dumą wsłuchuje się w nadawane przez niego audycje - od komunikatów meteorologicznych po koncert życzeń, ale także lekarz udzielający porad uchodźcom, często niepotrafiącym zrozumieć jego diagnozy, ale odczuwającym okazywaną im empatię. Kiedy bada kobietę w ciąży, usiłuje jej przekazać, że urodzi zdrową dziewczynkę, dodając ze smutkiem, iż być może ta wiadomość wcale jej nie cieszy. Zdaje sobie sprawę, że wiele z transportowanych kobiet podczas rejsów staje się ofiarą przemocy seksualnej i gwałtów pogłębiających ich traumę. Lekarz z irytacją mówi o komentarzach na temat rutynowości jego pracy, stwierdzając, że duże doświadczenie wcale przecież nie pomaga mu w wydawaniu kolejnych dokumentów stwierdzających zgon uchodźców, w tym dzieci w różnym wieku. Ilustracją jego zwierzeń są sceny z bieżącej akcji ratowniczej, dzięki której udaje się udzielić pomocy przynajmniej ocalałym członkom przewożonej grupy. Wydaje się, że główny bohater filmu, nastoletni chłopiec, nie przejmuje się kwestią uchodźców, choć ma świadomość ich nieustannej obecności w życiu swoim i najbliższych. Zdaje sobie sprawę, że kiedy wreszcie pokona chorobę morską i zacznie wypływać z ojcem na połów, będzie świadkiem rozgrywających się na morzu dramatów.

Rosi w swoim dokumencie zmienia perspektywy i przenosi akcenty ze sfery prywatnej i drobnych spraw domowych na sferę publiczną i oficjalne działania instytucji państwowych. W efekcie problem uchodźców staje się częścią rzeczywistości zwykłych ludzi, a nie wyłącznie polityki i przekazów medialnych. Podobny wątek konfrontacji społecznej z uchodźcami przewija się w kinie polskim, które na różne sposoby próbuje mierzyć się z trudnym tematem. „W drodze” rozgrywa się akcja krótkometrażowego filmu Hanoi-Warszawa Katarzyny Klimkiewicz z 2009 r., pokazującego dzieje młodej Wietnamki od momentu przybycia do Polski, gdy porzucona w lesie przez przemytników próbuje dotrzeć do centrum miasta. Kolejne epizody odtwarzają trasę bohaterki po Warszawie, gdzie usiłuje odnaleźć mężczyznę, dla którego zdecydowała się na emigrację. Jeszcze bardziej dramatyczna jest historia rozbitego gdzieś w Bieszczadach transportera z nielegalnymi pasażerami, pojawiająca się jako drugoplanowy, ledwie zasygnalizowany wątek w filmie Na granicy (2016) Wojciecha Kasperskiego. Fabuła przybiera formę opowieści inicjacyjnej, w której młodzi mężczyźni wykazują się siłą, odwagą i umiejętnością sprawnego działania - żadna $\mathrm{z}$ tych cech nie zostanie wykorzystana do ratowania ofiar wypadku ani ścigania osób stojących za przemytem uchodźców. Jeszcze bardziej drastyczne są losy przybysza w filmie Słońce, to słońce mnie oślepiło (2016) Anny i Wilhelma Sasnali. Dochodzi w nim do zabójstwa Obcego, na spotkanie z którym nikt nie jest przygotowany, zostają więc uruchomione mechanizmy wrogości, uprzedzeń i fobii. O tym, jak narracja o uchodźcach rozmija się z historią życia współczesnych bohaterów, opowiada film Via Carpatia (2018) 
Klary Kochańskiej i Kaspera Bajona rozgrywający się na szlaku ludzkiego przemytu przez Turcję, Grecję i Bałkany. Podróżująca para, zamiast dotrzeć z pomocą do ojca mężczyzny, Syryjczyka przebywającego w obozie dla uchodźców, w kluczowym momencie zmienia plany i decyduje się na wypoczynek na greckim wybrzeżu. Film dedykowano Abdulli Mostafie, z którym nie udało się spotkać.

Bohaterowie dokumentu Central Airport TPH znajdują się w znacznie lepszej sytuacji niż przybysze na Lampedusie, bowiem po dotarciu do Berlina zyskali opiekę lekarską, stałe zakwaterowanie i szansę na aplikowanie o azyl. Jednak wnętrze hali dawnego lotniska w centrum miasta funkcjonuje dokładnie w taki sam sposób, jak inne obozy dla uchodźców, jest wyizolowane i poddane stałemu nadzorowi. W swoich opisach obozów Agier zauważa, że każdy z nich jest skonstruowany, w swoim założeniu, jak autentyczna ,pustynia” (...) Wewnatrz w imie dobra ofiar i efektywności działań dla ich przetrwania, wytwarza się środowisko, w którym rozmowa $i$ wolność sa niepokojące i problemowe. Przestrzeń wspólna dla uchodźców, ich ,świat”, nie jest ani pożadany, ani przewidywany ${ }^{30}$. Przekonuje się o tym bohater filmu o berlińskim obozie lotniskowym Ibrahim al-Hussein, 18-letni uchodźca z Syrii czekający na prawo stałego pobytu w Niemczech. W staraniach towarzyszy mu Aïnouz dokumentujący za pomocą kamery codzienne sytuacje, rozmowy, spotkania z urzędnikami. Ibrahim często dzwoni do pozostałej w syryjskich miastach rodziny, marząc, że kiedyś będzie im mógł pomóc i ponownie uda im się spotkać. Jednak proces zaczynania życia od nowa jest niezwykle trudny i rozciągnięty w czasie. Zaskoczona urzędniczka z niedowierzaniem odnotowuje, że Ibrahim jest w obozie już ponad półtora roku, stwierdzając, że przecież miejsce to powstało z założeniem, iż nikt nie będzie w nim przebywał dłużej niż trzy miesiące. Ale to nie oczekiwanie najbardziej doskwiera uchodźcom na Tempelhof, lecz brak prawa do samodzielnego, indywidualnego życia. Wiąże się to nie tylko z trudnościami ze zdobyciem dokumentów i znalezieniem pracy w przestrzeni miasta, ale także $\mathrm{z}$ tak prozaicznym faktem, jak brak drzwi w boksach mieszkalnych. Każdy z ,pokoi” ma jedynie zasłonkę z materiału, niegwarantującą intymności, ale spełniającą wymogi bezpieczeństwa i zasad przeciwpożarowych. $\mathrm{Z}$ czasem lokatorom coraz trudniej przychodzi godzić się z liminalnością swojej siedziby oraz faktem, że w świecie obozu jest jedynie pusta przestrzeń, i taka pozostaje, pomimo dokonujących się $w$ nim prób odnowienia życia ${ }^{31}$. W jednej ze scen Ibrahim wspomina, że po przybyciu nikt ich nie uprzedził, że jadą na nieczynne lotnisko. Kiedy więc uchodźcy zobaczyli z okien autobusu stojące tam stare samoloty, myśleli, że zaraz zostaną nimi odesłani do kraju. Strach był tak duży, iż nie dostrzegli nawet archaiczności maszyn, niezdolnych w ogóle do lotów. Jak zauważył Agier, w kontekście obozowego ,życia na marginesie” przebiegający tam proces integracji zawsze pozostanie niekompletny.

Aki Kurismäki, jakby na przekór pesymistycznej diagnozie Agiera, nakręcił film Człowiek z Hawru (Le Havre, 2011), osadzając akcję w Normandii, gdzie problem uchodźców jest równie mocno obecny, jak w okolicach Calais. Zamiast jednak tworzyć realistyczną - i pesymistyczną - wizję egzystencji uchodźców w tymczasowych obozowiskach, zaproponował formę odczytaną jako ,polityczna bajka" ${ }^{32}$. Wykorzystał w niej poetykę francuskiej kultury popularnej lat 50. i 60., uznając, że najlepiej pasuje ona do prezentacji prowincji i małomiasteczkowego stylu życia opartego na wspólnotowości oraz solidarności społecznej. Zgodnie 
z wizją reżysera, kiedy w tytułowym porcie zostanie znaleziony kontener wypełniony nielegalnymi emigrantami z Afryki, mieszkańcy natychmiast się aktywizują. Nie tylko pomagają chłopcu o imieniu Idrissa ukryć się przed czekającą go deportacją, ale także zbierają pieniądze na opłacenie jego przemytu do matki mieszkającej w Londynie. Bezpośrednią inspiracją dla filmu były kontrowersje, jakie w 2009 r. wzbudziła decyzja francuskiego ministra do spraw emigracji o likwidacji „Dżungli” w Calais. Kurismäki włączył do swojej opowieści archiwalne aktualności z tego okresu, by stworzyć dla niej kontekst polityczny i zaznaczyć, że za fabularną historią kryją się autentyczne ludzkie dramaty. Dyskryminacja i ksenofobia zostają $\mathrm{w}$ filmie potraktowane $\mathrm{z}$ ironicznym humorem pozwalającym w krzywym zwierciadle pokazać uprzedzenia wobec obcych. W jednej ze scen główny bohater Marcel Max, czyszcząc buty klientowi, zerka na trzymaną przez niego gazetę, informującą na pierwszej stronie o przechwyconym nielegalnym transporcie ludzi. Krzyczący nagłówek: Uzbrojeni i niebezpieczni? Powiązania z al-Kaidą? jest zestawiony z fotografią kobiety siedzącej z dziećmi w ciemnym kontenerze, oraz działaczy Czerwonego Krzyża.

W Człowieku z Hawru realizm pojawia się wyłącznie podczas filmowania świata zewnętrznego, wrogiego wobec uchodźców. Sceny rozgrywające się we wnętrzach rybackich domów w stylu retro są ciepłe i barwne, a sztuczność scenerii jednocześnie podkreśla ich bajkowość i sielską atmosferę. Reżyser z premedytacją zestawił dokumentalne ujęcia portu z kampową inscenizacją prywatnych mieszkań, bowiem starał się unikać medialnej poetyki ukazywania uchodźców: Chciałem ich pokazać w najlepszych, niedzielnych strojach, do diabła z realizmem. Chciatem, aby przybyli jako dumni ludzie, a nie jako osoby wycieńczone, lezace we własnych odchodach, jak musiałoby to realistycznie wyglądać po dwóch tygodniach podróży w zamknięciu ${ }^{33}$.

Szczęśliwe zakończenie Człowieka z Hawru pokazujące dumę mieszkańców z dobrze wykonanego obowiązku humanitarnego wobec potrzebujących wpisuje się w realizowaną przez Kurismäkiego politykę utopijnej empatii, którą określa on mianem kontrfaktycznego utopizmu ${ }^{34}$. Polega ona na przedkładaniu idealistycznych wizji społecznego poczucia etyki i solidarności nad polityczne przesłania - jak to francuskiego ministra chcącego zlikwidować „Dżunglę” w Calais. Podobny utopizm jako rodzaj polityki autorskiej pojawia się w filmie Po tamtej stronie (Toivon tuolla puolen, 2019), którego akcję reżyser osadził w helsińskiej restauracji, gdzie dzięki pomocy właściciela i jego współpracowników znajduje schronienie syryjski uchodźca Khaled. Wystrój lokalu jest równie eklektyczny, jak serwowane w nim japońskie menu, zmienione zgodnie z potrzebą mody. Kulinarne transgresje zdają się przekładać na otwartość na obcych i wzajemne wsparcie członków załogi.

Koncepcja utopijnej empatii realizowana przez Kurismäkiego jest rodzajem alternatywy dla zdiagnozowanego przez Baumana bezprawia, panujacego na globalnym pograniczu ${ }^{35}$, którego ofiarą padają uchodźcy pozbawieni wsparcia władzy państwowej, mogącej upominać się o ich prawa. W swojej argumentacji Bauman odwołuje się do analizy Agiera, który po wizytach w licznych obozach stwierdził, że uchodźcy znajdują się w nich zawsze poza prawem; nie poza tym lub innym prawem tego lub innego kraju, lecz poza prawem w ogóle. Sa nowym rodzajem wyrzutków i ludzi wyjętych spod prawa, produktem globalizacji, esencją i najpetniejszym wcieleniem ducha pogranicza. Musza (...) ,,dryfować na granicy”, nie 
wiedzac, czy jest to stan przejściowy, czy trwaty ${ }^{36}$. W praktyce oznacza to, że osoby przebywające w obozach są stopniowo pozbawiane wszelkich wyróżniających znaków tożsamości, tworząc anonimową masę pozbawioną własnego państwa i miejsca na ziemi. Lektura tekstu Agiera tylko umacnia Baumana w obserwacji, że we współczesnym świecie uchodźcy to zawsze osoby z zewnątrz, ludzie-odrzuty globalnego pogranicza stanowiący uosobienie intruzów doskonatych, którzy zawsze $i$ wszędzie sa obcy i nigdzie nie maja własnego miejsca z wyjątkiem tych miejsc, które same nie maja miejsca i których próżno szukać na mapach używanych przez zwyklych ludzi ${ }^{37}$.

\section{Działanie}

Jako trzeci etap uchodźctwa Agier wskazuje działanie będące demonstracją przez uchodźców poczucia własnej podmiotowości i prawa do życia. Ślady umacniającej się samoświadomości można odnaleźć w decyzji Bilala z filmu Witajcie, dla którego przepłynięcie kanału to akt wolności wyboru. Na aktywność stawia również syryjski lekarz, który mimo zamknięcia na Tempelhof stara się kontynuować praktykę, sprawiającą, że nadal ma poczucie swojego profesjonalizmu i przydatności. Najbardziej subwersywne wobec mechanizmu wykluczenia i marginalizacji są działania bohaterów filmu Chus Guttiérez Powrót do Hansali (Retorno a Hansala, 2008). Główna bohaterka Leila decyduje się pokonać afrykański szlak w odwrotną stronę, co początkowo wcale nie jest związane z przymusową deportacją, lecz z koniecznością przewiezienia do Maroka ciała brata Rachida, który utonął, próbując przepłynąć przez „cieśninę śmierci”. Z czasem, „w drodze” jej działanie nabiera cech coraz bardziej świadomego sprzeciwu wobec drastyczności i nieuniknioności losu ludzi na przemytniczym szlaku. Reżyserka nawiązała do autentycznych wydarzeń, jakie miały miejsce w 2003 r., kiedy 37 osób z Maroka utopiło się w Zatoce Kadyksu. Aż trzynastu pasażerów łodzi pochodziło z górskiej miejscowości Hansala w regionie Beli Mellal zamieszkanym przez Berberów żyjących w warunkach skrajnej biedy, bez pomocy rządu ani żadnych instytucji. Około jednej czwartej Marokańczyków mieszkających w Hiszpanii pochodzi właśnie z tego regionu, z niego też wywodzi się najwięcej ofiar nielegalnych przepraw przez Cieśninę Gibraltarską. Chus Guttiérez po przeczytaniu artykułu na temat wypadku odwiedziła miejscowość i przeprowadziła wywiady z mieszkańcami, postanawiając, jak Winterbottom, połączyć wątek fabularny z autentycznymi postaciami i niemal etnograficzną dokumentacją miejsc i ludzi.

Ponieważ w Powrocie do Hansali podróż przebiega w przeciwną stronę niż migracja, jeszcze bardziej widoczne są rządzące nią reguły wyznaczone przez przemytników, którzy równie bezwzględnie czerpią profity ze szmuglowania żywych ludzi, jak i ciał ofiar własnego ,interesu”. Bohaterka filmu Leila mieszka już legalnie w Hiszpanii, skąd przesyła pieniądze dla rodziny i to właśnie od niej brat Rachid dostał sumę potrzebną na przeprawę. W podróży towarzyszy jej Martin, postać wzorowana na przemytniku z El Barrio, który podejmując się zlecenia, zmuszony jest poznać kulturę i motywacje uprzedmiotawianych dotąd uchodźców. Motywem, który pozwolił połączyć dwie narracje - powrotu i wcześniejszej migracji - stały się ubrania zdjęte z wyłowionych zwłok. W wiadomościach o wypadku w Zatoce Kadyksu reżyserka usłyszała bowiem, że resztki strojów ofiar zostały zabrane do Maroka w celu identyfikacji na ich podstawie tożsamości zmarłych pozbawionych jakichkolwiek dokumentów. Uderzyło ją, jak mocno strój jest na 
marokańskiej wsi związany z osobą, podczas gdy w zachodnim obiegu jest czymś masowym, skomercjalizowanym i najczęściej anonimowym. W jej filmie Leila i Martin powielają oficjalną procedurę i w każdej z odwiedzanych przez siebie marokańskich wiosek rozwieszają ubrania osób, które utopiły się wraz z Rachidem. Dramatyczna prezentacja stwarza szansę na przywrócenie zaginionym uchodźcom ich podmiotowości, historii rodzinnej i kulturowej. Uszanowanie resztek garderoby staje się etyczną powinnością wpisaną w proces transportu ciał, ich pochówku i utrwalenia ich losów w pamięci zbiorowej. Ubrania leżące w wodzie, na piasku lub na podłodze samochodu przekształcają się w materialne świadectwo, a zarazem wizualny symbol dramatu, który rozegrał się w trakcie podróży ich właścicieli. Wiszące na sznurach są jak duchy zmarłych osób, ponownie obecnych w swoich rodzinnych stronach. W jednej ze scen Said mówi do Martina, że jeśli mu się powiedzie, to też kiedyś będzie miał taki samochód jak on, a wtedy przyjedzie do domu i przywiezie rodzinie oraz przyjaciołom mnóstwo ładnych strojów. I nie będą to ubrania umarłych.

Zygmunt Bauman pisał o „obcych u naszych drzwi” w okresie najintensywniejszych przepływów migracyjnych z Bliskiego Wschodu pogrążonego w konfliktach wywołanych Arabską Wiosną. Jednak mimo zanurzenia w aktualności, rozpoczął swoje rozważania od przypomnienia, że masowa migracja nie jest zjawiskiem nowym, zwłaszcza że specyfiką nowoczesności jest to, iż tworzy grupy ludzi lokalnie nieużytecznych ${ }^{38}$ odrzucanych albo ze względu na postęp gospodarczy, albo z powodu niepokojów, konfliktów i sporów wywołanych przemianami społeczno-politycznymi i walkami o władzę. Tacy ludzie zawsze będą próbowali znaleźć dla siebie nowe miejsce, decydując się na życie „w drodze”, a konflikt wokół ruchów migracyjnych i uchodźstwa wynika jego zdaniem z tego, że świat zachodni nagle dostrzegł ludzkie resztki ${ }^{39}$ - i to w ilości masowej. Przyczyniło się do tego także kino „w drodze”, pokazując mechanizmy marginalizacji opisane przez Baumana i Agiera oraz złożoność migracji, o której François Gemenne pisze: Migracje to żadna szansa ani zagrożenie. To rzeczywistość XXI wieku, fakt społeczny nieodłacznie zwiąany z istnieniem świata, który cechuja głębokie nierówności ${ }^{40}$. Ciekawym podsumowaniem tematu masowej migracji jest film Christiana Petzolda Tranzyt (Transit, 2018), w którym nakładają się dwa doświadczenia migracyjne: z czasów II wojny światowej oraz z lat współczesnych. W plenerze współczesnej Marsylii patrolowanej przez służby kontrolujące uchodźców rozgrywa się akcja oparta na powieści Anny Seghers z 1942 r. ukazującej losy uciekinierów z nazistowskich Niemiec próbujących przedostać się za ocean. Scenariusz filmu zachowuje oryginalną literacką historię XX-wiecznych uchodźców z ich lękami, zagubieniem i poczuciem osamotnienia, jeszcze intensywniejsze w realiach późniejszych o ponad pół wieku. Brak szczegółów - dat, nazw miejsc - powoduje, że miotające się nerwowo po uliczkach postacie, spotykające się w zaułkach i kawiarniach, uosabiają uniwersalne doświadczenia uchodźców, naznaczone strachem i niepewnością bez względu na kontekst czasowy i polityczny. W jednej ze scen bohater ucieka na widok policjantów, którzy na ulicy legitymują zatrzymanych mężczyzn. Historyczna fabuła i współczesna sceneria płynnie przenikają się ze sobą w ponadczasową narrację życia „w drodze”.

Film Petzolda staje się niejako podsumowaniem współczesnego kina „w drodze", ukazując ciągłość i niezmienność struktury (droga, obóz, działanie) uchodź- 
czych narracji, bez względu na wybór konwencji przedstawiania. Jednocześnie jest to rodzaj wykładni dla refleksji Baumana, Agambena, Angiera, zwracających uwagę na nieuniknioność procesów migracyjnych, których dokumentalne i fabularne wizje mierzą się z doświadczeniem ,pozornie marginalnych” uchodźców.

MAŁGORZATA RADKIEWICZ

${ }^{1}$ H. Nafici, Accented Cinema. Exilic and Diasporic Filmmaking, NJ Princeton University Press 2001, s. 31.

${ }^{2}$ Tamże.

${ }^{3}$ Zob. Y. Loshitzky, Screening Strangers: Migration and Diaspora in Contemporary European Cinema, Indiana University Press, Bloomington 2010; K. Loska, Postkolonialna Europa. Etnoobrazy współczesnego kina, Universitas, Kraków 2016.

${ }^{4} \mathrm{M}$. Agier, On the margines of the World: The Refugee Experience Today, thum. D. Fernbach, Polity Press, Cambridge 2008 (Wyd. franc.: Aux Bords Du Monde, Les Réfiugiés, Editions Flammarion 2005).

${ }^{5}$ Tamże, s. VII.

${ }^{6}$ Tamże, s. 3.

${ }^{7}$ Tamże.

${ }^{8}$ Z. Bauman, Obcy u naszych drzwi, thum. W. Mincer, Wydawnictwo Naukowe PWN, Warszawa 2016, s. 102.

${ }^{9} \mathrm{G}$. Scalettaris, Uchodźcy, migranci-na czym polega różnica? W: Migranci, migracje. O czym warto wiedzieć, by wyrobić sobie własne zdanie, red. H. Thiollet, tłum. M. Szczurek, Karakter, Kraków 2017, s. 102.

${ }^{10}$ Tamże, s. 104.

${ }^{11}$ Agier wymienia także Palestyńczyków, których uznaje za „historycznych” uchodźców od lat koczujących na ograniczonych terytoriach. M. Agier, dz. cyt. s. 3.

${ }^{12}$ Z. Bauman, Życie na przemiat, thum. T. Kunz, Wydawnictwo Literackie, Kraków 2004, s. 13.

13 Tamże, s. 113.

14 Tamże, s. 115.

15 Tamże, s. 119.

16 Wywiad Jessiki Winter dla „The Village Voice”, 23.09.2003, cyt. za: M. Winterbottom, Interviews, red. D. Smith, University Press of Mississipi, Jackson 2011, s. 61.

${ }^{17}$ M. Agier, dz. cyt., s. 2-3.

${ }^{18}$ Z. Bauman, Obcy... dz. cyt., s. 118.

${ }^{19}$ Zob. Jestem kapitan Rackete $i$ mam zasady. Z Carolą Rackete rozmawia Fabio Tonacci (Przedruk za „La Repubblica”, 6.07.2019)
„Gazeta Wyborcza. Magazyn Świąteczny” 20-21.07.2019, s. 14-15.

${ }^{20}$ Z. Bauman, Obcy... dz. cyt., s. 117.

${ }^{21}$ Zob. M. Agier, Managing the Undesirables: Refugee Camps and Humanitarian Government, thum. D. Fernbach, Polity, Cambridge 2011, s. 4. Cyt. za: Z. Bauman, Obcy ... dz. cyt., s. 101.

${ }^{22}$ Tamże.

${ }^{23}$ G. Agamben, My uchodźcy, thum. K. Gawlicz, w: Agamben. Przewodnik Krytyki Politycznej, Wydawnictwo Krytyki Politycznej, Warszawa 2010, s. 30.

${ }^{24}$ Tamże, s. 31.

${ }^{25}$ G. Agamben, Homo Sacer: Suwerenna wtadza i nagie życie, tłum. Mateusz Salwa, Prószyński i S-ka, Warszawa 2008, s. 232.

${ }^{26}$ Zob. P. Mościcki, Migawki z tradycji uciśnionych, Książka i Wiedza, Teatr Polski Bydgoszcz, Bydgoszcz-Warszawa 2017, s, 131.

${ }^{27} \mathrm{M}$. Agier, Czy obozy umożliwiaja lepsze zarządzanie populacjami uchodźców?, cyt. za: Z. Bauman, Obcy... dz. cyt., s. 3.

${ }^{28}$ Tamże.

${ }^{29}$ Tamże.

${ }^{30} \mathrm{M}$. Agier, On the margines of the World ... dz. cyt., s. 39.

${ }^{31}$ Tamże, s. 40.

${ }^{32}$ I. Ballesteros, Immigration Cinema in the New Europe, Intellect, Bristol 2015, s. 163.

${ }^{33}$ Tamże, s. 165.

34 Tamże, s. 166.

${ }^{35}$ Z. Bauman, Życie... dz. cyt., s. 120.

${ }^{36}$ Zob. M. Agier, Auxs bords du monde, les réfugiés, Paris 2002, s. 55-56, cyt. za: Z. Bauman, Życie...dz. cyt, s. 120.

${ }^{37}$ Z. Bauman, Życie... dz. cyt., s. 120.

${ }^{38}$ Z. Bauman, Obcy... dz. cyt., s. 9.

${ }^{39}$ Tamże, s. 102.

${ }^{40} \mathrm{~F}$. Gemenne, Migracje - szansa czy zagrożęnie? w: Migranci, migracje. O czym warto wiedzieć, by wyrobić sobie własne zdanie, red. H. Thiollet, thum. M. Szczurek, Karakter, Kraków 2017, s. 183. 